Article

\title{
Pengaruh Perendaman Asam Nitrat pada Pemrosesan Nasi Instan untuk Menurunkan Indeks Glikemik
}

\author{
Joko Waluyo ${ }^{1, *}$,Yusi Prasetyaningsih ${ }^{2}$, Fenny Tri Ariyani ${ }^{1}$, dan Ida Maya Sari ${ }^{1}$ \\ 1 Program Studi Teknik Kimia, Universitas Sebelas Maret, Surakarta \\ 2 Progeam Studi Teknik Kimia, Politeknik TEDC Bandung, Cimahi \\ E-mail: *jokowaluyo@staff.uns.ac.id (Corresponding author)
}

\begin{abstract}
Rice is the main food for most people in Indonesia. Cooking rice takes about 40-50 minutes. Instant rice is a solution for cooking rice in a relatively short time through a process of precooking and drying. The purpose of this study is to make instant rice with a low glycemic index so that it can be consumed by people with diabetes mellitus. The method used in making this instant rice is soak - cook - freeze - dry it. The rice is soaked using $2-7 \% \mathrm{Na}$-citrate solution at $50^{\circ} \mathrm{C}$, for 2 hours. The ratio of rice with a soaking solution is $1: 2$. Rice is needed up to $\mathrm{pH} 7$ then accepted using ricecookerz. Cooked rice is frozen in the freezer at $-4^{\circ} \mathrm{C}$ for 24 hours. Rice which has been liquefied by thawing process uses warm water at $60^{\circ} \mathrm{C}$. Rice is then heated at $70^{\circ} \mathrm{C}$ for $4-5$ hours. Instant rice is ready to be brewed (rehydrated) using boiling water. Instant rice rehydration time reaches 5.49 minutes. The glycemic index test results showed an instant glycemic index value of 51.69 with a nutrient content that did not change significantly like the original rice. The results show that making instant rice vy soaking-cookingfreezing -drying can reduce the glycemic index.
\end{abstract}

Keywords: quick cooking rice, rehydration time, glycemic index

EQUILIBRIUM Volume 4 No.1 July 2020

Online at http:// equilibrium.ft.uns.ac.id 


\section{Pendahuluan}

Beras merupakan bahan pangan pokok bagi sebagian besar penduduk Indonesia. Beras mengandung karbohidrat yang sangat diperlukan oleh tubuh. Kandungan gizi beras per $100 \mathrm{~g}$ bahan adalah $360 \mathrm{kkal}$ energi, 6,6 g protein, 0,58 g lemak, dan 79,34 g karbohidrat (USDA, 2011) [1]. Beras yang dimasak menjadi nasi membutuhkan waktu pemasakan sekitar 30 - 40 menit. Akan tetapi seiring perkembangan dan kemajuan teknologi beras dapat diproses menjadi nasi cepat saji atau nasi instan. Beras dapat dimasak dengan metode quick cooking rice sehingga menjadi beras instan dan dapat disajikan dalam waktu singkat. Pada dasarnya beras instan atau nasi instan dibuat dengan menurunkan kadar airnya dan membuat struktur beras tersebut menjadi berongga. Sehingga pada saat pengolahan, cukup dengan penambahan air panas maka beras akan menjadi nasi dalam waktu yang singkat.

Nasi instan diproduksi dengan cara memberi perlakuan pada beras untuk membuatnya menjadi pourus sehingga air dan panas lebih cepat terserap ke dalam biji beras. Teknologi dan cara pengeringan beras menentukan jenis dan mutu nasi instan yang dihasilkan. Nasi yang telah dikeringkan masih mampu menyerap air kembali dalam jumlah yang besar. Sifat inilah yang digunakan dalam pembuatan nasi dan bubur instan, yaitu dengan cara memasak beras sampai tanak lalu dikeringkan. Setelah dimasak, diharapkan nasi instan tetap mempunyai rasa, aroma, tekstur, warna seperti nasi biasa. Begitu pula nilai gizi dan komposisi yang terkandung di dalamnya diharapkan tetap seimbang sehingga dapat diproduksi dalam jumlah banyak [2].

Selain bertujuan untuk membuat produk cepat saji, pada penelitian ini dilakukan rekayasa untuk menurunkan indeks glikemik pada nasi instan. Hal tersebut bertujuan untuk membantu para penderita diabetes miletus agar tetap bisa menikmati nasi. Penderita diabetes melitus (DM) menghindari konsumsi nasi karena dapat meningkatkan kadar glukosa darah dengan cepat.. Oleh karena itu salah satu cara yang dapat digunakan untuk membantu penderita diabetes adalah dengan membuat nasi dengan indeks glikemik rendah.

Indeks glikemik (IG) merupakan suatu ukuran untuk mengklasifikasikan pangan berdasarkan pengaruh fisiologisnya terhadap kadar glukosa darah [3]. Makanan dikategorikan memiliki IG tinggi jika mempunyai nilai lebih dari 70, sedangan dikategorikan rendah jika nilai IG kurang dari 55. Nasi putih mempunyai indeks glikemik tinggi sebesar $73 \pm 4$ yang dapat menyebabkan peningkatan respon glukosa darah dan insulin. Untuk menghindari hal tersebut penderita diabetes dianjurkan mengonsumsi nasi dengan indeks glikemik yang rendah yaitu kurang dari 55. Diperlukan metode pengolahan untuk menurunkan indeks glikemik pada nasi.

\section{Metode Penelitian}

\subsection{Bahan}

Bahan baku berupa beras jenis Ciherang dibeli dalam bentuk gabah dari balai benih Tegalgondo, Kartasura, Sukoharjo, Jawa Tengah. Gabah tersebut dimasukkan penggilingan padi di daerah Jatipuro, Karanganyar, Jawa Tengah agar diperoleh beras untuk dijadikan bahan baku. Natrium sitrat berasal dari sigma aldrich. Pembuatan nasi instan dilakukan di Laboratorium Proses Teknik Kimia Universitas Sebelas Maret Surakarta.

\subsection{Prosedur Penelitian}

Beras ditimbang sebanyak 100 gram. Kemudian beras direndam dalam larutan natrium sitrat dengan konsentrasi 3\%, 5\%,6\%, dan 7\% dalam $200 \mathrm{~mL}$ air. Perendaman dilakukan selama 2 jam pada suhu $30^{\circ} \mathrm{C}$ dan $50^{\circ} \mathrm{C}$. Beras yang telah direndam kemudian ditiriskan dan dicuci dengan air hingga $\mathrm{pH}$ menjadi netral $(\mathrm{pH} 7)$. Beras yang telah dicuci dimasak menggunakan rice cooker dengan perbandingan beras: air sebesar 1 : 1,5 dan juga $1: 2$. Nasi yang telah masak, didinginkan kemudian dibungkus dan dibekukan di dalam freezer pada suhu $-4^{\circ} \mathrm{C}$ selama $24 \mathrm{jam}$. Nasi yang telah beku kemudian dilanjutkan dengan proses thawing dengan cara memanaskan air dalam water bath hingga suhu $60^{\circ} \mathrm{C}$, kemudian nasi beku (masih terbungkus plastik) direndam dalam air tersebut. Thawing dilakukan selama kurang lebih 5 menit hingga nasi kembali menjadi empuk dan berbulir. Dalam proses ini nasi dijaga agar tidak terlalu panas dan lembek kembali.

Nasi diletakkan di atas loyang dan diatur sedemikian rupa agar proses pengeringan dapat terjadi secara merata. Pengeringan dilakukan menggunakan oven. Suhu pengeringan divariasi pada $50^{\circ} \mathrm{C}, 70^{\circ} \mathrm{C}$ dan $90^{\circ} \mathrm{C}$ hingga diperoleh berat konstan nasi kering. Pengeringan pada suhu $90^{\circ} \mathrm{C}$ memerlukan waktu $3,5-4$ jam, 
suhu $70^{\circ} \mathrm{C}$ memerlukan waktu selama $5-7 \mathrm{jam}$, sedangkan pengeringan pada suhu $50^{\circ} \mathrm{C}$ memerlukan waktu selam 12 - 13 jam.

Nasi yang telah dikeringkan sudah menjadi nasi instan. Selanjutnya dilakukan proses rehidrasi atau penyeduhan nasi kering menggunakan air mendidih. Nasi yang telah ditimbang dengan berat yang sama diletakkan di dalam wadah mangkok alumunium foil. Kemudian diseduh dengan air mendidih. Satu sampel diseduh dengan volume air yang berbeda, yaitu air yang setara dengan tinggi nasi kering dan air yang berlebih. Kemudian waktu rehidrasi dihitung mulai dari penyeduhan dengan air panas. Suhu air mendidih berkisar antara $97-98^{\circ} \mathrm{C}$.

\subsection{Uji Nilai Indeks Glikemik}

Pengujian indeks glikemik memerlukan satu set lengkap alat pemeriksaan gula darah yaitu strip analisis glukosa, lancet, kapas steril, glukometer. Sampel darah sebanyak $0,5 \mu \mathrm{dL}$ diambil setiap 30 menit menggunakan metode finger-prick capillary blood samples. Menurut Susanti (2018), kriteria inklusi responden untuk uji indeks glikemik adalah responden yang memiliki indeks massa tubuh (IMT) normal yaitu $18,5-25,0 \mathrm{~kg} / \mathrm{m}^{2}$, berusia 20-30 tahun Sampel darah tersebut dimasukkan ke dalam strip analisis glukosa [4]. Alat glukometer akan menunjukkan hasil pembacaan kadar gula darah yang diuji. Pengujian ini melibatkan 5 responden mahasiswa. Responden melakukan puasa selama $10 \mathrm{jam}$. Kemudian responden berbuka dengan mengonsumsi 127 gram nasi instan matang.

Pengecekan sampel darah responden dilakukan setiap 30 menit selama 2 jam. Sebagai pembanding pengujian nasi instan dengan indeks glikemik rendah, responden diuji dengan mengkonsumsi roti tawar dan penambahan toping berupa susu kental manis serta gula pasir. Roti tawar dan gula pasir merupakan makanan yang mengandung indeks glikemik 100. Hasil pengujian kadar gula darah setiap pengambilan sampel diolah menggunakan aplikasi microsoft office excel menjadi grafik hubungan antara waktu pengambilan sampel (sumbu x) dengan kadar gula darah (sumbu y). Perhitunga IG menggunakan metode Incremental Area Under The Blood Glucose Response Curve. [5]. Nilai IG dihitung berdasarkan perbandingan antara luas kurva kenaikan glukosa darah setelah mengkonsumsi pangan yang di uji dengan kenaikan glukosa darah setelah mengkonsumsi pangan rujukan terstandar, seperti glukosa dan roti [6].

Rumus perhitungan nilai IG adalah sebagai berikut :

$$
I G=\frac{\text { Luas area kurva pangan uji }}{\text { Luas area dibawah kurva pangan standar }} \times 100 \%
$$

Nilai IG pangan berkisar antara 1-100 dan dibagi dalam tiga level, yaitu rendah $(<55)$, sedang $(55-70)$ dan tinggi (>70) [1].

\section{Hasil dan Pembahasan}

\subsection{Pengaruh bahan perendam dan suhu perendaman}

Pembuatan nasi instan dengan indeks glikemik rendah diawali dengan penentuan konsentrasi bahan perendam yang digunakan untuk membuat struktur beras menjadi porous. Menurut Peraturan Kepala Badan POM No. 18 Tahun 2013 tentang Batas Maksimum Penggunaan BTP sekuestran, penggunaan Na - Sitrat hingga 7\% berat masih diperbolehkan. Oleh karena itu, $\mathrm{Na}$ - Sitrat dipilih sebagai bahan perendam dalam pembuatan nasi instan dengan nilai indeks glikemik rendah. 


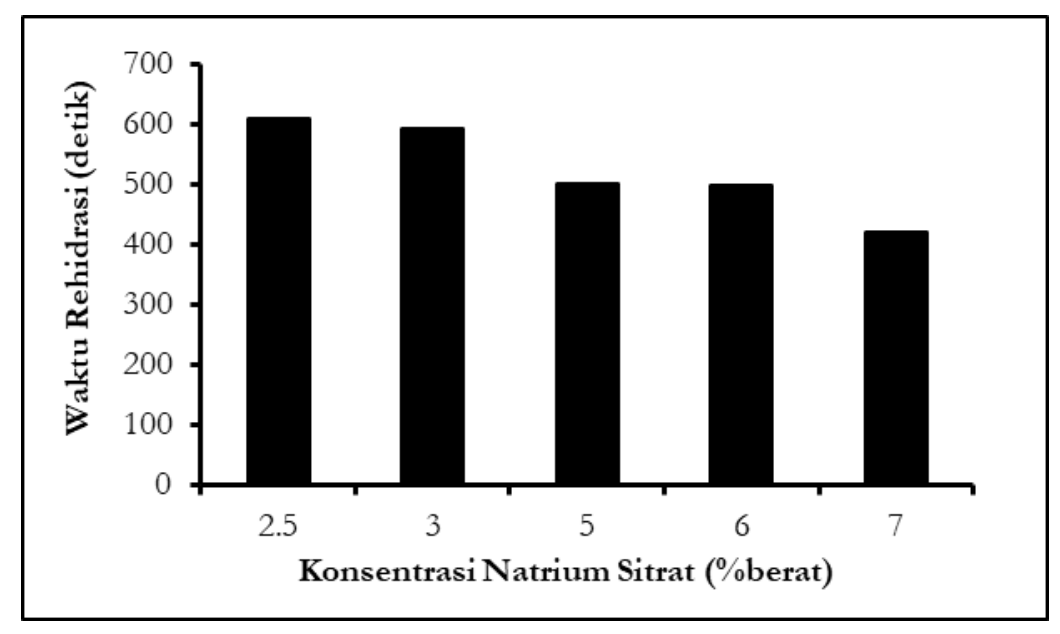

Gambar 1. Pengaruh Konsentrasi Na-sitrat terhadap Waktu Rehidrasi

Dari hasil percobaan yang ditunjukkan Gambar 1 terlihat bahwa semakin besar konsentrasi Na-sitrat maka waktu rehidrasi nasi instan semakin cepat. Perendaman beras dalam larutan sodium sitrat akan mengganggu dan menguraikan struktur protein beras, sehingga butiran menjadi porous. Menurut Luna, P. (2015), garam sitrat ini tidak banyak berpengaruh bila digunakan tersendiri [7], oleh karena itu untuk menghasilkan beras instan yang diinginkan, penggunaan garam sitrat dilakukan bersama dengan perlakuan pemanasan pada suhu $50^{\circ} \mathrm{C}$.

Hal tersebut sesuai dengan percobaan yang telah dilakukan dalam pembuatan nasi instan. Perendaman beras dengan Na-sitrat 7\% yang dilakukan tanpa pemanasan menghasilkan waktu rehidrasi nasi instan selama 427 detik. Sedangkan, beras yang direndam Na-sitrat $7 \%$ serta dipanaskan pada suhu $50^{\circ} \mathrm{C}$ waktu rehidrasi nasi instan lebih singkat, yaitu 349 detik. Pemanasan pada saat perendaman dilakukan pada suhu $50^{\circ} \mathrm{C}$ merupakan variabel bebas yang dipilih dalam pembuatan produk. Pemanasan dilakukan untuk mengoptimalkan proses penguraian struktur beras, sehingga butirannya menjadi lebih porous (berongga). Struktur porous beras akan mempermudah proses rehidrasi butiran nasi instan untuk menjadi nasi kembali.

\subsection{Pengaruh suhu pengeringan terhadap tampilan nasi instan}

Percobaan pembuatan nasi instan dari varietas padi ciherang menggunakan rasio air dan beras 1,5: 1 dan 2 : 1. Penggunaan rasio air dan beras $1,5: 1$ pada pemasakan awal nasi sedikit pera dibandingkan pemasakan dengan rasio $2: 1$. Hasil rehidrasi nasi instan dengan rasio pemasakan $2: 1$ lebih empuk dibandingkan rasio pemasakan $1,5: 1$. Oleh karena itu, pembuatan nasi instan dengan indeks glikemik rendah menggunakan rasio pemasakan air : beras sebesar $2: 1$.

Selain itu variasi temperatur yang digunakan dalam pengeringan nasi instan juga berpengaruh pada tampilan nasi instan kering. Variasi temperatur yang digunakan untuk mengeringakan nasi instan adalah $50^{\circ} \mathrm{C}$, $70^{\circ} \mathrm{C}, 90^{\circ} \mathrm{C}$. Semakin tinggi temperatur yang digunakan maka waktu yang diperlukan untuk pengeringan semakin singkat. Akan tetapi, semakin tinggi suhu akan menyebabkan tekstur nasi instan kering menjadi pecah - pecah. Nasi instan yang dikeringkan pada suhu $90^{\circ} \mathrm{C}$ memerlukan waktu pengeringan selama 3,5- 4 jam. Hasil pengamatan nasi instan tampak pecah - pecah dan warna menjadi agak kekuningan. Pengeringan pada suhu $70^{\circ} \mathrm{C}$ memerlukan waktu pengeringan selama $5-7$ jam. Hasil pengamatan nasi instan tampak lebih menarik untuk dijual karena lebih terlihat utuh, butiran tidak tampak pecah dan warnanya masih mirip dengan beras biasa. Selain itu untuk suhu pengeringan $50^{\circ} \mathrm{C}$ memerlukan waktu pengeringan selama $12-13$ jam. Hasil pengamatan nasi instan tampak utuh dan warnanya tampak bersih. Akan tetapi suhu tersebut kurang efektif apabila digunakan untuk produksi skala besar, karena waktu pengeringan yang lama dapat memicu tumbuhnya jamur pada nasi yang dikeringkan.

\subsection{Uji Organoleptik}

Uji organoleptik merupakan analisa tampilan fisis dan rasa dari nasi instan. Pengujian ini melibatkan responden sebanyak 20 orang yang diminta untuk menilai tampilan fisik dari nasi instan dan memberi 
penilaian dari hasil nasi tersebut. Ada 6 parameter yang akan di analisa, yaitu kenampakan, tekstur, warna, aroma, rasa dan kesukaan terhadap nasi instan. Uji Organoleptik Nasi Instan dengan Indeks Glikemik Rendah disajikan pada Tabel 1.

Tabel 1. Hasil Uji Organoleptik Nasi Instan Matang (Setelah Rehidrasi)

\begin{tabular}{lcccccc}
\hline Penilaian & \multicolumn{6}{c}{ Parameter yang di analisa } \\
Responden & Kenampakan & Tekstur & Warna & Aroma & Rasa & Kesukaan \\
\cline { 2 - 7 } Rata-Rata & 3,5 & 3,4 & 3,4 & 3,4 & 3,6 & 3,5 \\
\hline
\end{tabular}

Berdasarkan Tabel 1 dapat diketahui bahwa nasi instan yang telah diproduksi dari penilaian skala 1 - 4 menunjukkan kecenderungan yang baik dengan kata lain cukup diminati oleh konsumen.

\subsection{Uji Indeks Glikemil Nasi Instan}

Responden penelitian yang terpilih adalah mahasiswa D3 Teknik kimia Universitas Negeri Sebelas Maret. Responden berjumlah 4 orang terdiri dari dua orang laki-laki dan dua orang perempuan. Rata-rata usia responden dalam penelitian ini adalah 21 tahun. Berat badan responden berkisar antara $50-65 \mathrm{~kg}$ dan tinggi badan berkisar antara $150-161 \mathrm{~cm}$. Responden yang dipilih merupakan responden yang memiliki status gizi normal, tidak memiliki gangguan metabolisme glukosa ditunjukkan dengan hasil pemeriksaan Gula Darah Puasa (GDP) dalam batas normal yaitu rata-rata GDP adalah $81 \mathrm{mg} / \mathrm{dL}$.

Berdasarkan Gambar 2 dapat diketahui kenaikan kadar glukosa standar lebih tinggi dibandingkan dengan kadar kenaikan glukosa dari nasi instan. Dari hasil penelitian diperoleh nilai indeks glikemik nasi instan sebesar 51,69. Oleh karena itu, nasi instan dapat dikategorikan dalam makanan dengan indeks glikemik rendah.

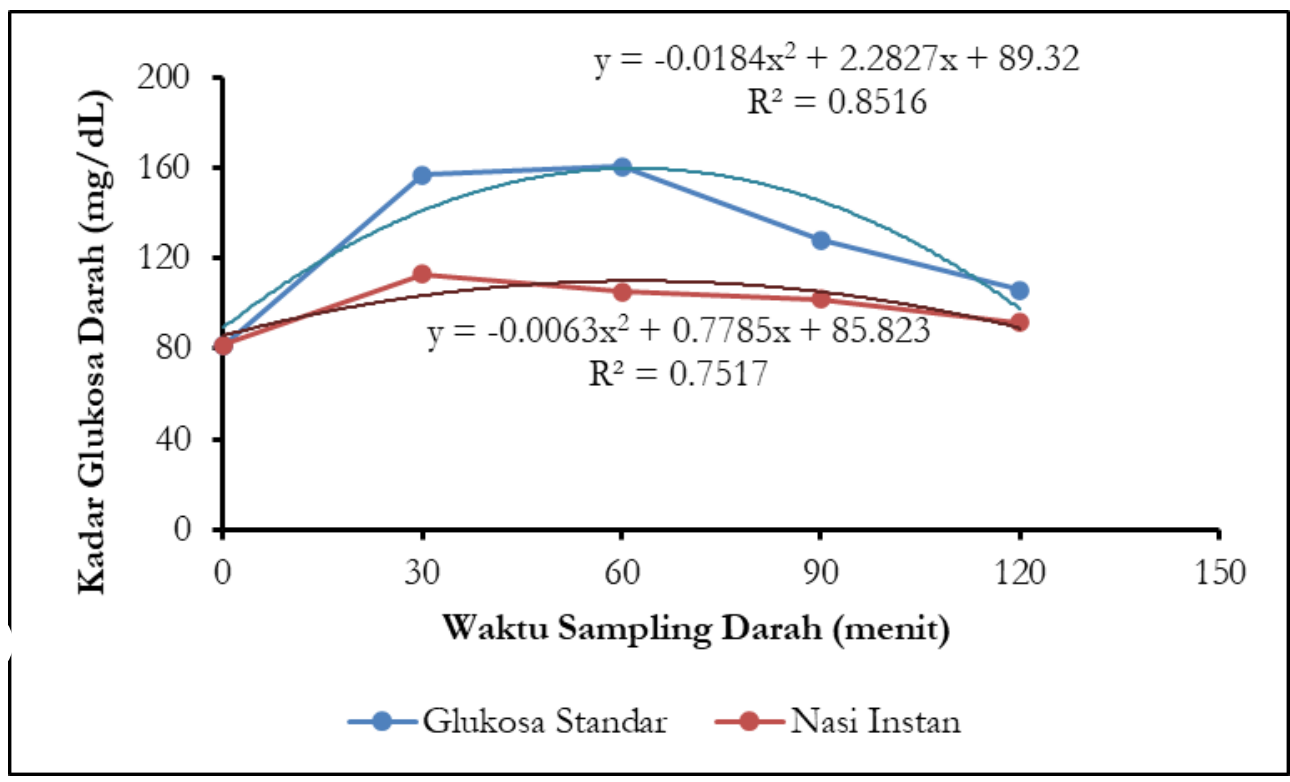

Gambar 2. Grafik Kenaikan Kadar Glukosa Darah Responden

\subsection{Hasil Uji Waktu Layak Konsumsi}

Uji waktu layak konsumsi dilakukan dengan cara pengamatan pada nasi instan yang disimpan dalam kemasan plastic zap selama 3 bulan. Pengecekan dilakukan setiap satu minggu sekali dengan parameter berupa warna, aroma, dan ada atau tidak adanya jamur yang tumbuh pada nasi instan. Hasil pengamatan dari minggu ke-1 hingga minggu ke-12 menunjukan tidak adanya perubahan warna dan aroma serta tidak ada jamur yang tumbuh pada nasi instan.

Pengaruh Perendaman Asam Nitrat pada Pemrosesan Nasi Instan untuk Menurunkan 


\subsection{Hasil Uji Nutrisi}

Uji nutrisi bertujuaan untuk mengetahui kandungan nutrisi dari nasi instan yang telah dihasilkan. Kandungan yang diuji antara lain karbohidrat, gula total, lemak, protein, kalori dan natrium. Pengujian dilakukan di Balai Riset dan Standarisasi Industri (Baristand), Surabaya.

Tabel 2 Hasil Uji Nutrisi

\begin{tabular}{clcc}
\hline No & Parameter & Nasi instan & Nasi biasa \\
\hline 1 & Gula total $(\%)$ & Tidak terdeteksi & Tidak terdeteksi \\
2 & Protein $(\%)$ & 3,36 & 3,89 \\
3 & Karbohidrat $(\%)$ & 21,57 & 22,88 \\
4 & Lemak $(\%)$ & 0,23 & 0,06 \\
5 & Natrium $(\%)$ & 0,88 & 0,78 \\
6 & Kalori (kkal/100g) & 101,84 & 107,88 \\
\hline
\end{tabular}

Berdasarkan hasil uji nutrisi yang ditunjukkan Tabel 2, nasi instan memiliki kandungan nutrisi yang mirip dengan nasi biasa serta memiliki kelebihan yaitu kandungan karbohidrat dan kalori yang lebih rendah, sehingga cocok dikonsumsi bagi penderita diabetes mellitus. Kandungan karbohidrat dan kalori sebanding dengan indeks glikemik nasi. Semakin rendah karbohidrat dan kalori semakin rendah pula nilai indeks glikemik.

\section{Kesimpulan}

Pembuatan nasi instan dengan indeks glikemik rendah dengan metode Rendam-Rebus-Kukus-Keringkan yang dimodifikasi telah berhasil dilakukan. Berdasarkan uji kelayakan yang dilakukan dalam 3 bulan kondisi fisik dari nasi instan masih tetap sama dan tidak terjadi perubahan warna, serta tidak adanya jamur yang tumbuh. Berdasarkan uji indeks glikemik, dari 5 responden didapatkan indeks glikemik rata-rata setelah makan nasi instan sebesar 51,69. Hal ini menunjukan bahwa indeks glikemik pada nasi instan berada pada kategori makanan dengan indeks glikemik rendah.

\section{Daftar Pustaka}

[1] E. Septianingrum, Liyanan, B. Kusbiantoro, "Review Indeks Glikemik Beras: Faktor-Faktor yang Mempengaruhi dan keterkaitannya terhadap Kesehatan Tubuh". Jumal Kesehatan, Vol.1, Hal 1-9, 2016

[2] B. Pamungkas, B. Susilo, N. Komar, "Uji Fisik dan Sifat Kima Nasi Instan (IRSOYBEAN) Bersubsitusi Larutan Kedelai (Glycine max)". Jurnal Keteknik Pertanian Tropis dan Biosistem, Vol. 1, Hal 213-223, 2013

[3] A. B. Arif, A. Budiyanto, Hoerudin, "Indeks Glikemik Produk pangan dan Faktor-Faktor yang Memengaruhinya”. Jumal Litbang Pert., Vol. 32, Hal 91-99, 2013

[4] A. Susanti, A. Wijanarka, A. S. Nareswara, "Penentuan Indeks Glikemik dan Beban Glikemik pada Cookies Tepung Beras Merah (Oryza nivara) dan Biji Kecipir (Psophocarpus tetragonolobus. L), Ilmu Giz̨i Indonesia, Vol.02 No.1, Hal 69-78, 2018

[5] A. Istiqomah, N. Rustanti, "Indeks Glikemik, Beban Glikemik, Kadar Protein, Serat, dan Tingkat Kesukaan Kue Kering Tepung Garut dengan Subtitusi Tepung Kacang Merah”, Journal of Nutrition College, Vol 4. No 4, Hal 620-627, 2015

[6] Y. Marsono, P. Wiyono, Z. Noor, "Indeks Glisemik kacang-kacangan (Glycemic Index of Selected Legumes)", Jurnal Teknologi dan Industri Pangan, Vol. 13, No. 3, Hal 211, 2012

[7] P. Luna, H. Herawati, S. Widowati, A. B. Prianto, "Pengaruh Kandungan Amilosa terhadap Karakteristik Fisik Organoleptik Nasi Instan", Jurnal Penelitian Pascapanen Pertanian, Vol. 12, No. 1, Hal $1-10,2015$ 